\title{
Designing Tolerance Learning in Higher Education to Prepare Students as Global Citizens
}

\author{
Asep Mahpudz ${ }^{1, *}$, Anthonius Palimbong ${ }^{2}$ \\ ${ }^{1,2}$ Tadulako University, Palu, Indonesia \\ *Corresponding author.Email: asepmahpudz@gmail.com
}

\begin{abstract}
ABSTRCT
One of the important aspects observed in the association of students in higher education today is the attitude of tolerance towards other people. At the Teaching and Education Faculty of Tadulako University, many students come from various ethnicities, religions, regions and have different language backgrounds. Tadulako University students have heterogeneous and multicultural characteristics. In the context of this research, it focuses on the design of a tolerance learning model in preparing students as global citizens. The writing of this article uses a descriptive qualitative research approach with a case study method. The tolerance learning design developed is oriented to make a good contribution to efforts to reveal tolerance values for students and appreciate the reality of diversity that exists in the campus environment. Preparing students as global citizens, among others; (1) students can respect themselves; (2) being respectful of others; (3) being respectful of their living environment; (4) respect the truth
\end{abstract}

Keywords: Global Citizens, Higher Education, Tolerance Learning Design.

\section{INTRODUCTION}

The attitude of tolerance is currently a concern in Indonesia. This research is important because until now, there is very little information that is based on research regarding the attitude of tolerance in student associations on campus. Aspects that need to be considered include the attitude of tolerance among students. This research emphasizes more on efforts to strengthen tolerance learning in students while studying on campus and in socializing within the campus environment. We view that tolerance on campus should be implemented. This can be done by creating a conducive campus culture.

The main purpose of learning tolerance for students is to encourage student associations who can live together comfortably, respect each other, support each other in a harmonious life. They can appreciate the differences they have, both in religion, language, and different ethnic and cultural backgrounds.

Basically, the foundation of education in Indonesia, which is based on the basic values of Pancasila, really appreciates the diversity of the Indonesian people. Therefore, in the education process in Indonesia, including in the learning process in universities, more attention should be paid to aspects of tolerance learning. In the implementation of education in Indonesia, the aspect of respect for human dignity is an important foundation. Educational efforts in higher education are oriented towards understanding and awareness of differences and the importance of being developed. Therefore, the learning process in higher education needs to prepare students as citizens who will live life in the future. Citizens who will live in the future, it is important to understand the differences and know the steps and actions to deal with differences that are owned by humans. Students can socialize and communicate with others openly, and inclusively. Tolerant attitudes and actions from humans like this can be fostered through the education process that is currently planned.

In the implementation of higher education in Indonesia today and in the future, what is important to note is the diversity in the community on campus. Therefore, it is necessary to continue to develop tolerance and mutual respect for each difference. Facing an increasingly dynamic life in the 21 st century, the campus environment in higher education can become an environment as a heterogeneous place. This is because of the differences in students, lecturers, who come from 
various ethnic groups, religions, customs, cultures. Tadulako University as a higher education institution has a role in fostering a culture of democracy and the growth of tolerance among students. The focus of this research problem is revealed in the research questions: (1) How is the planning and implementation model of student tolerance learning in universities to prepare $21 \mathrm{st}$ Century skills? (2) What is the model format that can be developed in terms of planning and implementing tolerance learning in universities as an effort to prepare students as global citizens?

\section{THEORETICAL REVIEW}

\subsection{The Concept of Tolerance in the Dynamics of Social Life in the Global Era}

Indonesia as a nation has a variety of potential resources and diverse cultures, from ethnicity, language, religion, and customs. [1]. Therefore, fostering and internalizing tolerant attitudes and actions must continue to be developed as an effort to prevent conflict. In terms of diversity in Indonesia, tolerant attitudes and actions are good social capital for Indonesia in maintaining unity as a country. This needs to be maintained. Indonesia, which has a variety of cultures from different ethnic groups, different religions in society, and many regional languages, if tolerant attitudes and actions are not developed, can lead to conflict. [2]. From the review of several studies that have been carried out, information is obtained that the existence of economic and social inequality can be a trigger for social conflict. If the public does not get the correct information comprehensively, there can be different views and assumptions that can be wrong. As a result, there will be conflict in society. Therefore, in a heterogeneous society, it is important to develop mutual respect and tolerance for differences. [3].

Conceptually, Tolerance is an attitude that is shown in the form of action based on awareness of differences, mutual respect for others. [4]. [5]. Tolerance is an attitude or trait of a person to allow freedom to others and to give the truth about these differences as an acknowledgment of human rights. The implementation of this attitude of tolerance must be based on an attitude of spaciousness towards others by paying attention to the principles that are held by themselves, namely without sacrificing these principles. Tolerant attitudes and actions can be realized if there is mutual respect and good understanding of all the differences they have. [6].

Tolerant attitudes and actions can be realized by growing awareness and self-disclosure to accept and appreciate the differences they have. It is possible that each person in socializing has differences in aspects of ethnicity, language, religion, and cultural background. From this understanding, it can be argued that to foster and maintain tolerance in a heterogeneous society will require knowledge, openness, communication, freedom of thought, and trust. [7]. There are two different views regarding tolerance. At first glance, tolerant attitudes and actions will be able to develop without starting with prejudice. So, the existence of prejudice is an intolerant attitude. In the second view, tolerant attitudes and actions are different from prejudice. However, in this view, the prejudice aspect is an indicator to see tolerant attitudes and actions towards the group. [8].

\subsection{Citizenship Education in Higher Education in Indonesia}

Higher Education is an institution that is trusted by the community as a place to give birth to human resources who are smart, intelligent, good, and able to become leaders in the community. [9]. Higher education as a place to learn life for students needs to be always ready to change for the better. This can be done by being open and adapting to the changes that occur. The new paradigm of policy on higher education shows a change in the management of higher education which was originally centralized to become decentralized. [10]. All higher education institutions in Indonesia have different philosophical foundations, historical backgrounds as well as vision and mission, organization, and leadership models, but are still bound to one goal, namely to become a quality, superior and healthy university. [11].

According to Article 4 of Law Number 12 of 2012 concerning higher education, it is stated about the functions of higher education, namely: developing abilities and shaping character; develop innovative, creative, skilled, competitive attitudes through education, research and community service, as well as developing Science and Technology with human values. [12].

To carry out these three functions, universities must be able to organize learning that is very supportive of the potential development of each student and an effective learning process. Learning activities must be able to create opportunities and opportunities for students to develop global competencies. [13]. In the context of future education development, the student learning process in higher education must place students as young citizens and at the same time as part of the world's citizens. Therefore, it is important to develop intensive efforts in guiding and directing students to be ready to face the challenges of life in the future. In this view, what deserves to be developed is an educational process that provides opportunities for students to think and act according to their abilities. In addition, the learning process in higher education places more emphasis on preparing them to participate actively in social problems that will be faced. [14]. Students who study are positioned as learning subjects and are able to develop themselves optimally. Campuses (including 
educators) are expected to cooperate with other educational institutions to share information and experiences about the practices and learning methods they have developed.

With regard to the function of Indonesia's national education, it has been clearly described through the National Education System Law Number 20 of 2003. Indonesian national education functions to develop abilities and shape the dignified character of students. One of the goals of Indonesian national education is to make students democratic and responsible citizens. To achieve this goal, it can be done through civic education. [15].

The implementation of higher education should be directed to; (1) produce graduates who meet the demands of community life competencies in global dynamics, (2) provide educational services that are in accordance with the interests and demands of the community, develop all student potential (personality, knowledge, social skills), (3) build harmonious relationships between educators and participants who based on mutual need.

Through the provisions of regulations from the Director General of Higher Education, Ministry of Education and Culture of the Republic of Indonesia number $84 / \mathrm{E} / \mathrm{KPT} / 2020$, it has been regulated on the implementation of compulsory courses and must be included in the Indonesian higher education curriculum. The compulsory subjects are (1) Religion, (2) Pancasila, (3) Citizenship, and (4) Indonesian. [16].

The Pancasila Education course aims to provide students with an understanding and awareness of the ideology of the Indonesian people. The content of the study material for this course includes; (1) Introduction to Pancasila Education; (2) The study of Pancasila in the history of the Indonesian nation; (3) The basis of the state is Pancasila; (4) Pancasila as ideology; (5) Pancasila as a Philosophical System; (6) Pancasila as an ethical system; and (7) Pancasila as the basic value of the development of science and knowledge.

The Citizenship Education course aims to improve students' understanding of the basics of the Indonesian state, the Constitution of the unitary state of the Republic of Indonesia, the form of the Indonesian state and Bhineka Tunggal Ika. This course also aims to build student awareness as citizens who have a sense of nationalism and pride as the Indonesian nation. The contents of citizenship education include: (1) Introduction to citizenship education; (2) national identity; (3) national integration; (4) Constitution in Indonesia; (5) material on rights and obligations as citizens; (6) the development of democracy in Indonesia; (7) Law enforcement in Indonesia; (8) insight into the archipelago; and (9) national resilience.
The orientation of future citizenship education is not only to prepare good and smart citizens, it is also important to be directed at preparing young citizens who are able to actively participate in global society. It should be realized that at this time the world seems to be without national borders, so in the current era what is important is the way citizens are able to solve problems according to their abilities.

\subsection{The Concept of a Global Citizen}

The concept of a global citizen was actually born along with the rapid flow of globalization. Global citizenship itself arises from diversity itending to expand inclusion and power and has an ethical and normative framework and is far from just a tool of power. As a process, globalization has brought significant changes to world civilization. [17].

Now, the world seems to be borderless, human movement both physically and ideas are becoming increasingly out of control, traveling through space and time can be done by anyone, anytime and anywhere. Citizens are faced with the development of a very fast era that touches various areas of the nation's life both politically, economically, socially, culturally, and so on. This increasingly high and intense global dependence that involves nations around the world requires the involvement of citizens around the world to actively seek alternative solutions to problems faced together. This reality, of course, creates the world in a condition of inevitable interdependence.

Global citizen in a broad sense refers to individuals who prioritize and prioritize the identity of "global citizens" above their identity as communal citizens. In a narrower sense, this means the emergence of individual attitudes that prioritize the interests and needs of world citizens above the interests of their communal groups, even above their own interests. Global citizens are not just ordinary communal or national citizens, but deeper than that the meaning of global citizens focuses on aspects of abilities, skills possessed by a person so that they can contribute to the future of the world and longterm human survival. [18].

Cogan provides several characteristics of citizens associated with current global trends. The characteristics that must be seen and possessed by a global citizen are: 1. Solve problems with a global citizen approach. 2 . Work together with others. 3. Responsible for the roles and responsibilities of citizens. 4. Think critically and systematically. 5. Resolve conflicts non-violently. 6 . Implement a lifestyle that is in harmony with the environment. 7. Respect and defend human rights. 8. Participate in public affairs at all levels of civics learning; and utilize information-based technology.[19]. 


\section{METHODS}

This research is a type of qualitative research by applying a descriptive approach. The process of collecting data is carried out by interviewing techniques, and distributing questionnaires. [20]. This research was conducted in July - September 2020. The research locations are in thirteen study programs at the Faculty of Teacher Training and Education, Tadulako University. Research respondents are students who have studied Citizenship Education courses. The process of analyzing research data is carried out through steps by collecting data and information, detecting the collected data, presenting data and information that is the result of reduction, and interpreting the data to make conclusions. The step of triangulation of methods and data sources is carried out to validate the data and information. [21].

\section{RESULTS AND DISCUSSION}

\subsection{Fostering a Tolerant Attitude Towards Students}

One of the important aspects observed in the association between students in universities today, among others, is related to the attitude of tolerance towards other students, including lecturers and other communities. In the Faculty of this research location, namely FKIP UNTAD, there are a number of students who come from various ethnic groups, religions, regions and have different language backgrounds. This indicates that Tadulako University FKIP students have heterogeneous and multicultural characteristics.

This study collects information through interviews and distributes questionnaires to students. From the results of interviews and the results of processing the questionnaire, information was obtained that the tolerant attitudes and actions of students were in the fairly good category. This needs to be encouraged more intensively to be able to behave tolerantly. The existence of a character learning process in religious education, Pancasila education and citizenship education in higher education has a good impact on the development of student tolerance.

Good character values, such as honesty, fairness and respect, empathy, sympathy and helping weak friends, have developed well among students. The emergence of cases of intolerance and conflict in society in recent years in Central Sulawesi, has brought the students' alertness not to be easily provoked by the issue of intolerance between people of different religions and different cultures. This shows that lecturers have played a fairly effective role in fostering the character of tolerance values for students.

Conducive learning conditions in the campus environment have contributed to the cool and peaceful situation and conditions in the last two years. The leadership's policy in developing an academic atmosphere is sufficient to support a comfortable and peaceful learning atmosphere at Tadulako University.

In this context, it is important to continue to develop tolerance learning for students, both through learning in the subjects of Religious Education, Pancasila Education and Citizenship Education. This has shown that the character of tolerance values in students has developed well. Tolerance learning is feasible to continue to be developed in the design of a permanent and continuous learning model. Exploration of tolerance values that have developed in students can be developed into an integrated learning model design in several relevant courses, and scientific courses in each of the existing study programs.

Efforts to raise awareness as a global citizen need to be encouraged. The important thing is to realize the ability of students to understand themselves as part of a global society, which requires knowledge, perspectives, and the ability to think and act as part of a global citizen.

\subsection{Designing Tolerance Learning which is integrated in Citizenship Education}

Learning models that can be developed to strengthen tolerance learning in higher education by emphasizing systematic procedures and planned learning experiences. Design The learning model in question is a procedure and procedure for carrying out a learning process that supports the development of tolerance character values. The process of designing tolerance learning models in higher education needs to be based on the value system prevailing in higher education. The diversity of student backgrounds is a consideration in developing the design of this tolerance learning model. The design of tolerance learning models can be developed to achieve graduate competence in the $21 \mathrm{st}$ century. At least with the design of this learning model, it can facilitate learning outcomes that are more oriented to the achievement of graduate competencies with creative, collaboration, communication and critical thinking abilities. 


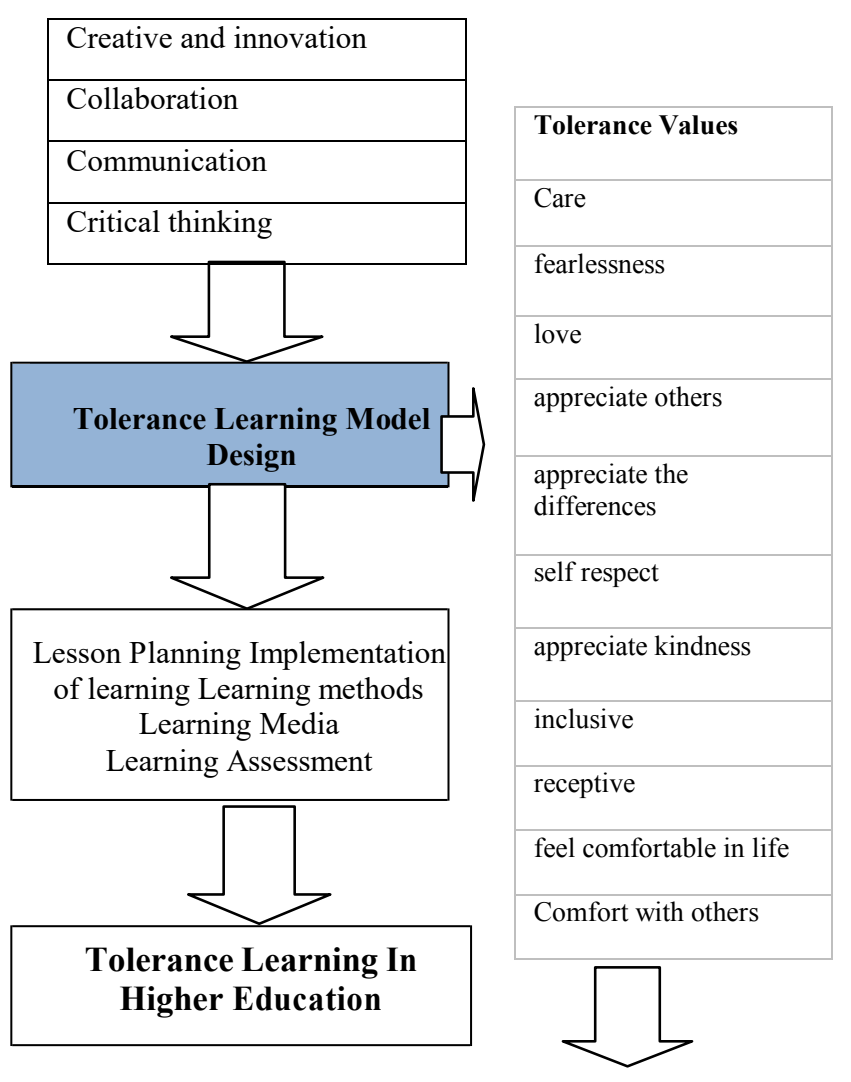

Figure 1: The relationship between 21st Century competencies and the values of tolerance that will be developed

The development of tolerance learning carried out is directed at preparing students as citizens and global citizens to have good and creative skills. This is done seriously and continuously to strengthen the values, attitudes and tolerant actions as good character. Preparing students with tolerant attitudes and actions is a good step to prepare them for the future. Good character, tolerant attitudes and actions will become students' social capital in life in the future.

The design of the tolerance learning model developed is expected to contribute to the formation of students' good character. What is really expected is that students can appreciate differences, and feel comfortable living life. Therefore, it is worth emphasizing to students, among others; (1) personally, students can respect themselves; (2) respect for others; (3) respect for their environment; (4) an attitude of appreciating the truth.

As an effort to form smart and good global citizens, it is important to develop a caring attitude towards the condition of society, and an attitude to be able to make changes for the better. Caring attitude means having the ability in the perspective of being a global citizen.
Citizenship Education not only provides awareness as a citizen and part of a global citizen, but also provides insight in the form of understanding the

condition of the Indonesian nation and also the condition of the world. Students need to have insight in developing themselves and Citizenship Education provides the insights needed by students. [22]. The content of basic values that are important to be developed in global citizens can be done through civic education in higher education. If this thinking can be accepted, then the values of tolerance are important to be developed in civic education in higher education. These values of tolerance will always be needed in future life. It really depends on good lesson planning in civic education now.

The position of higher education in producing current and future human resources is very strategic. Graduates of higher education are often regarded as qualified human beings, so that what is produced is often considered to be able to influence the views and thoughts of the community. Even the opinion of the graduates of higher education is often regarded as the truth, so that people imitate or follow it. Therefore, it is important to prepare students well so that they can become quality graduates of higher education. This self- quality is shown by a good way of thinking, behaving and acting. [23].

The learning process Civic education in higher education in the future is important to be oriented towards preparing young citizens to be ready to live in the future. It is certain that the challenges that will be faced will be different from today's. Raising awareness as part of a global citizen is also important to instill in students today. Therefore, growing awareness as a global citizen deserves attention in civic education in Indonesia. For this reason, steps to strengthen aspects of global thinking, critical and tolerant attitudes, and good social skills need to be developed as part of civic education in higher education. In turn, if this is successful, it will foster active participation and dare to make decisions and contribute to solving problems.

\section{CONCLUSION}

First, one aspect that is important to observe in the relationship between students in higher education today is related to the tolerance attitude of students towards other students, towards lecturers and the community. In the faculty of teaching and education at Tadulako University, many students come from various ethnic groups, religions, regions and have different linguistic backgrounds. This indicates that the community on campus has heterogeneous and multicultural characteristics. This is the basis for the importance of learning tolerance to be developed in higher education. 
Second, the tolerance learning model that can be developed in higher education is by emphasizing on

systematic concepts and procedures, as well as revealing learning experiences. The design of the tolerance learning model is a procedure and procedure for carrying out a learning process that supports the development of tolerance character values. The process of designing this learning model is also important based on the value system that applies in each university.

Third, the design of tolerance learning to prepare students as global citizens, among others; (1) students can respect themselves; (2) being respectful of others; (3) being respectful of their environment; (4) be respectful of the truth.

\section{AUTHORS' CONTRIBUTIONS}

Two authors have contributed from planning, carrying out the research to the end of writing this article.

\section{ACKNOWLEDGMENTS}

Researchers thank the faculty leaders who have funded this research in 2020. In addition, thank you to the students who have been willing to become respondents and informants of this research.

\section{REFERENCES}

[1] N. Simarmata et al., "Digital Press Social Sciences and Humanities Gotong Royong in Indonesian History Psychology 2019 Gotong Royong in Indonesian History," 2019.

[2] A. Mahpudz, Jamaludin, and A. Palimbong, "Tolerance Learning to Develop Students Social Skills in the 21st Century," 2020, vol. 458, no. Icssgt 2019, pp. 169-178, doi:10.2991/assehr.k.200803.022.

[3] M. Czepil, O. Karpenko, A. Revt, and K. Istomina, "Formation of Students' Ethnic Tolerance in Institutions of Higher Education," Adv. Educ., vol. 6, no. 12, pp. 114-119, 2019, doi: $10.20535 / 2410-8286.168675$.

[4] T. A. Baklashova, E. M. Galishnikova, and L. V.Khafizova, "The effects of education on tolerance: Research of students' social and ethnic attitudes," Mediterr. J. Soc. Sci., vol. 6, no. 1S3, pp. 335-340, 2015, doi: 10.5901/mjss.2015.v6n1s3p335

[5] Pusat Studi Islam dan Kenegaraan Indonesia(PSIK-Indonesia), Indonesia Zamrud Toleransi, no. 11. 2017.
[6] B. Arifin, "Implikasi prinsip tasamuh (toleransi) dalam Interaksi Antar Umat beragama," Fikri, vol. 1, no. 2, 2016.

[7] I. Fadillah, "Indonesia Negara Paling Tinggi Menjunjung Toleransi,"jurnalintelejen.net, no. june, pp. 1-3, 2017, [Online]. Available: http://jurnalintelijen.net/2017/06/09/indonesianegara-paling-menjunjung-tinggi-toleransi/.

[8] M. Hjerm, M. A. Eger, A. Bohman, and F. Fors Connolly, "A New Approach to the Study of Tolerance: Conceptualizing and Measuring Acceptance, Respect, and Appreciation of Difference," Soc. Indic. Res., vol. 147, no. 3, pp. 897-919, Feb. 2020, doi: 10.1007/s11205-01902176-y.

[9] R. Lawrence, L. F. Ching, and H. Abdullah, "Strengths and Weaknesses of Education 4.0 in the Higher Education Institution," Int. J. Innov. Technol. Explor. Eng., vol. 9, no. 2S3, pp. 511519, 2019, doi: 10.35940/ijitee.b1122.1292s319.

[10] S. Muhammad, "Kepemimpinan dalam Sistem Penjaminan Mutu Pendidikan Tinggi," J. Ilm. Widya, vol. 2, no. 3, pp. 56-67, 2014, [Online]. Available:http://digilib.mercubuana.ac.id/manage r/t!@file_artikel_abstrak/Isi_Artikel_1230576566 07.pdf.

[11] S. Supriyono, “Analisa Sistem Penjaminan Mutu Internal Pembiayaan Perguruan Tinggi Dengan Pendekatan Gap Analysis (Studi Kasus : Perguruan Tinggi X), ” JITMI (Jurnal Ilm. Tek. dan Manaj. Ind., vol. 1, no. 1, pp. 29-36, 2018, [Online].Available:http://openjournal.unpam.ac.i d/index.php/JITM/art icle/view/1403.

[12] D. Rahadian, "Pergeseran Paradigma Pembelajaran Pada Pendidikan Tinggi," J. PETIK, vol. v. 2, n. 1, no. may, pp. 1-7, 2018, doi: https://doi.org/10.31980/jpetik.v2i1.60

[13] L. Morgan, "Developing Civic Literacy and Efficacy: Insights Gleaned through the Implementation of Project Citizen.," I.E.Inq. Educ., vol. 8, no. 1, p. 3, 2016.

[14] S. Zahabioun, A. Yousefy, M. H. Yarmohammadian, and N. Keshtiaray, "Global citizenship education and its implications for curriculum goals at the age of globalization," Int. Educ. Stud., vol. 6, no. 1, pp. 195-206, Jan. 2013, doi: 10.5539/ies.v6n1p195.

[15] E. S. Nurdin, "The Policies on Civic Education in Developing National Character in Indonesia," Int. Educ. Stud., vol. 8, no. 8, Jul. 2015, doi:10.5539/ies.v8n8p199.

[16] Direktur Jenderal Pendidikan Tinggi, "Kepdirjen Dikti Nomor 84/E/KPT/2020 tentang Pedoman 
Pelaksanaan Mata Kuliah Wajib Pada Kurikulum Pendidikan Tinggi."

[17] L. A. Braskamp, "Developing Global Citizens," J.Coll. Character, vol. 10, no. 1, 2008, doi:10.2202/1940-1639.1058.

[18] H. Kishino and T. Takahashi, "Global citizenship development: Effects of study abroad and other factors," J. Int. Students, vol. 9, no. 2, pp. 535559, 2019, doi: 10.32674/jis.v9i2.390.

[19] Syaifullah, I. Affandi, and M. N. Somantri, "Civic Education, Global Issues, and Global Citizen," vol. 418, no. Acec 2019, pp. 541-545, 2020, doi: 10.2991/assehr.k.200320.102.

[20] J. W. Creswell, Research design: qualitative, quantitative, and mixed methods approaches, 4th ed. SAGE Publications, Inc, 2014.

[21] G. R. Somantri, "Memahami Metode Kualitatif," Makara, Sos. Hum., vol. 9, no. 2, pp. 57-65, 2005, [Online].

Available: https://media.neliti.com/media/publications/4388ID-memahami-metode-kualitatif.pdf.

[22] R. Yamanto, D. Budimansyah, and P. Bestari, "Civic Education Role for Devolved Student Awareness As a Global Citizen," Civicus, vol. 19, no.1, pp. 23-31, 2015, doi: 10.17509/civicus. v15i1. 2067.

[23] S. Peach and R. Clare, "Global Citizenship and Critical Thinking in Higher Education Curricula and Police Education: A Socially Critical Vocational Perspective," J. Pedagog. Dev., vol. 7, no. 2, pp. 46-57, 2017. 